УДК 374.7(100-69=112.2+477)

UDC 374.7(100-69=112.2+477)

DOI: $10.31475 /$ ped.dys.2018.25.10

НЕЛIНА ХАМСЬКА,

кандидат педагогічних наук, доиент

(Украӥна, Вінниия, Вінницький державний педагогічний університет імені Михайла Коцюбинського, вул. Острозького, 32)

NELINA KHAMS'KA,

candidate of pedagogical sciences, associate professor (Ukraine, Vinnytsia, Vinnytsia Mykhailo Kotsiubynskyi

State Pedagogical University, Ostrozkoho str., 32)

ORCID: 0000-0001-5567-9266

ДМИТРО МАТІЮК, аспірант

(Украйна, Вінниия, Вінницький державний педагогічний університет імені Михайла Коцюбинського, вул. Острозького, 32)

DMYTRO MATIIUK, postgraduate student (Ukraine, Vinnytsia, Vinnytsia Mykhailo Kotsiubynskyi State Pedagogical University, Ostrozkoho str., 32)

ORCID: 0000-0002-1169-2896

\title{
Освіта дорослих в німецькомовних країнах та перспективні напрями іiі розвитку в Україні
}

\section{Adult Education in German-Speaking Countries and Perspective Directions of its Development in Ukraine}

У статті обгрунтовано актуальність дослідження освіти впродовж життя, висвітлено основні ідеї Концепиї освіти дорослих в Україні. На основі аналізу психолого-педагогічних джерел окреслено причини, які гальлують процес розвитку освіти дорослих в Украӥні. Висвітлено окремі напрялки розвитку освіти впродовж життя у німецькомовних крайнах Європи та виокремлено перспективні ідеї екстраполяції у вітчизняну освітню систелу. Розкрито передумови розвитку освіти дорослих в нілеиьколовних країнах. Проаналізовано освітню діяльність інституцій, які сприяють розвитку освіти впродовж життя $в$ німеиьколовних країнах. Висвітлено проект Нілецької Асоиіації освіти дорослих "talentCAMPиs" ma багатомовний портал "Portal Deutsch». Систематизовано прогресивні надбання німеиьколовних країн в галузі освіти дорослих, які варто екстраполювати у вітчизняну освітню систелу. Представлено обговорення вмотивованості дорослого населення до неперервної освіти. Зроблено висновок, що розробка системи освіти дорослих та ї̈ впровадження в Україні на основі прогресивного досвіду європейських краӥн забезпечить особистісне та професійне зростання кожного гроладянина Украӥни та сприятиме фбормуванню суспільства знань.

Ключові слова: освіта дорослих, Концепиія освіти дорослих, німецьколовні країни, екстраполяція, неперервна освіта, освіта впродовж життя, інноваційний проект.

The importance of lifelong learning is explained in the article. The main ideas of the Conception of adult education in Ukraine are highlighted.

The aim of this research is to analyze the activity of educational institutions in German-speaking countries, that support the development of lifelong learning, and to find perspective directions of education throughout life improvement in Ukraine. Achievement of the suggested aim involves the use of a set of methods: historically-structural in order to sort out pedagogical literature and to represent historiography of this problem; comparative in order to single out organizational and technological aspects of adult education development in Ukraine; extrapolation - for studying the tendencies of lifelong learning development in German-speaking countries and their creative transfer to the Ukrainian educational space.

In the course of our research we have analyzed the preconditions of adult education development in German-speaking countries. The main institutions, that support the development of lifelong learning in German-speaking countries, are singled out: Bundesinstitut für Berufsbildung, Deutsches Institut für 
Erwachsenenbildung, der Deutsche Volkshochschulverband, Deutsche Gesellschaft für wissenschaftliche Weiterbildung und Fernstudium.

The studying of the adult education development in German-speaking countries has given us an opportunity to highlight perspective directions of extrapolation into Ukrainian educational system. They are the following: creation of the adult education institute network vertically - from central educational institutions to regional and local; development of conceptual foundations of this lifelong education level, specification of content, forms, methods and learning tools of adult education; implementation of innovative projects, that would provide access of adults to different forms of lifelong learning and would give an opportunity to deepen knowledge and improve professional competence without leaving the working place.

Discussions concerning adult's motivation to lifelong learning are analyzed. It was concluded that the development of adult education system and its implementation in Ukraine based on progressive experience of German-speaking countries will ensure personal and professional growth of every citizen of Ukraine and will contribute to the knowledge society formation.

Key words: adult education, the Concept of adult education, extrapolation, German-speaking countries, lifelong education, education throughout life, innovative project.

Вступ / Introduction. Освіта дорослих відіграе ключову роль у розвитку сучасного суспільства. Ї̈̈ актуальність зростае у зв'язку з переходом суспільства від освіти на все життя до освіти впродовж життя.

3 огляду на це провідні країни Свропи та світу активно розробляють і впроваджують нові нормативні документи, стратегії розвитку, програми освіти дорослих.

Одним із джерел, яке збагатило б вітчизняну українську освіту, є досвід розвитку освіти впродовж життя в німецькомовних країнах, оскільки він $е$ найбільш прогресивним i результативним на лоні світових тенденщій поширення неперервної освіти.

Надання кожному українцю можливості брати участь у програмах з освіти для дорослих, які засвідчили свою ефективність у німецькомовних країнах, дасть змогу підтримувати рівень освіченості українського суспільства, який відповідав би потребам сьогодення.

Мета та завдання / Aim and Tasks. Мета статті - проаналізувати діяльність освітніх інституцій німецькомовних країн, які сприяють розвитку освіти впродовж життя та визначити перспективні напрямки удосконалення неперервної освіти в Україні.

Методи / Methods. Для проведення дослідження було використано такі методи:

- історико-структурний був використаний 3 метою здійснення структуризації вітчизняної педагогічної літератури, з метою представлення історіографії досліджуваної проблеми та здійснення аналізу вітчизняних, зарубіжних джерел, матеріалів періодичної преси;

- порівняльно-зіставний - 3 метою виявлення організаційних, процесуально-змістових, технологічних аспектів розвитку освіти дорослих в Україні;

- екстраполяції - для вивчення сформованих у минулому і сьогоденні стійких тенденцій розвитку освіти протягом життя в німецькомовних країнах $\mathrm{i}$ творче перенесення його в український освітній простір.

Результати / Results. Аналіз світового досвіду розвитку освіти дорослих свідчить, що тривалий час ця галузь розвивалася за загальнопедагогічними принципами та не мала суттевих відмінностей. У 1833 р. німецький учитель вищої школи Олександр Капп (Alexander Kapp) вперше вжив термін «андрагогіка», який розглядаеться як теорія навчання дорослих. Ця наука вивчає зміст, форми, методи та засоби організації навчання дорослих людей з метою полегшення цього процесу, вдоволення їхніх освітніх потреб, підвищення операціональності отриманої освіти під час вирішення життевих проблем, досягнення індивідуальних цілей, самореалізації особистості (Official site of andragogy lead by Professor J. Raistmann, 2018).

Передумовами подальшого розвитку освіти дорослих став промисловий переворот XVIIIXIX століть у провідних європейських країнах, який зумовив зростання вимог до освіченості та професійної кваліфікації дорослого населення. Саме тому в цей час великим попитом почали користуватися дистанційні школи та інституції освіти дорослих (Матіюк Д., 2018).

Після завершення Другої світової війни в країнах Європи були розроблені програми для колишніх військовослужбовців, яким потрібні були нові знання та навики для швидшої інтеграції у післявоєнне суспільство. Свідченням актуальності зазначеної проблематики прогресивних країн світу є міжнародні конференції з освіти дорослих під егідою ЮНЕСКО (CONFINTEA), які в післявоенний період проходили у Ельзінорі (Данія, 1949), Монреалі (Канада, 1960), Токіо (Японія, 1972), Парижі (Франція, 1985), Гамбурзі (Німеччина, 1997), Бангкок (Тайланд, 2003), Белем (Бразилія, 2009), Сувон (Корея, 2017) (UNESCO Institute for Lifelong Learning, 2018).

У ході дослідження ми проаналізували перспективні напрямки розвитку освіти дорослих в 
німецькомовних країнах (Німеччина, Австрія, Швейцарія, Ліхтенштейн, Люксембург). Передумови впровадження та зазначена проблематика е актуальними, оскільки система освіти цих країн входить до числа найуспішніших та найперспективніших в Європі, і має певні напрацювання, які довели свою ефективність (Матіюк Д., 2018).

Розглядуваний нами напрям е складовою неперервної освіти німецькомовних країн, яка включае наступні види навчання: формальне (formal), неформальне (non-formal) та інформальне (informal) (Council of Europe. Formal, non-formal and informal learning, 2018).

Нами була проаналізована освітня діяльність наступних інституцій, які сприяють розвитку освіти дорослих в німецькомовних країнах: Федерального інституту профресійної освіти та підготовки (Bundesinstitut für Berufsbildung - BIBB), Німецького інституту освіти дорослих (Deutsches Institut für Erwachsenenbildung), Німецької Асоціації освіти дорослих (Der Deutsche Volkshochschulverband - DVV), Німецького товариства академічної безперервної освіти (Deutsche Gesellschaft für wissenschaftliche Weiterbildung und Fernstudium), до складу якого входять освітні заклади Австрії, Німеччини, Швейцарії.

Головною метою вищезазначених інституцій е наукові дослідження з напрямку використання передового світового досвіду з розвитку програм підвищення кваліфікації та практична підтримка освіти дорослих.

Протягом 50 років Федеральний інститут професійної освіти та підготовки (Bundesinstitut für Berufsbildung - BIBB) здійснюе наукову діяльність в напрямку розвитку професійної освіти та підвищення кваліфікації дорослих у Німеччині. Важливим $е$ те, що визначено правову основу діяльності інституту, що забезпечуе виконання його основних завдань. До ключових напрямків роботи інституту належать «Berufsbildungsforschung und Berufsbildungsmonitoring» («Дослідження та моніторинг професійної освіти»), «Struktur und Ordnung der Berufsbildung» («Структура та організація професійного навчання»), «Berufsbildung International» («Міжнародний розвиток профресійної освіти») та «Initiativen für die Berufsbildung» («Ініціативи для професійної освіти»). Основними завданнями вищезазначеної організації е надання можливостей для якісних наукових досліджень з проблематики освіти дорослих, політичне консультування урядових організацій 3 освітніх питань, забезпечення якості професійного навчання, систематизація переліку професійних кваліфікацій, підтримка культурних проектів, моніторинг післядипломної підготовки дорослих, підтримка національного агентства «Bildung für Europa» («Освіта для Європи»). Варто зазначити, що профорієнтаційне консультування як одна із форм роботи з дорослим населенням сприяе забезпеченню їх актуальними кваліфікаціями для зростання економічного і соціального майбутнього країни та підсилюе позиції Німеччини з огляду на тенденції розвитку її ринку праці (Bundesinstitut für Berufsbildung, 2018).

Німецький інститут освіти дорослих (Deutsches Institut für Erwachsenenbildung) здійснюе дослідження з питань освіти впродовж життя, перспективних програм підвищення кваліфікації та забезпечення можливостей неперервної освіти дорослих (Deutsches Institut für Erwachsenenbildung. Leibniz-Zentrum für lebenslanges Lernen, 2018).

Ключовими завданнями Німецького інституту освіти дорослих е:

1. Проведення досліджень інноващійних практично-оріентованих форм та методів роботи 3 дорослими.

2. Підготовка інфраструктури для проведення досліджень.

3. Передача знань шляхом проведення семінарів, тренінгів, воркшопів, вебінарів, он-лайн курсів дорослому населенню.

4. Розвиток інноваційних конщепцій для практичного застосування.

5. Надання консультацій щодо національної та міжнародної освітньої політики (Deutsches Institut für Erwachsenenbildung. Leibniz-Zentrum für lebenslanges Lernen, 2018).

Потужним структурним підрозділом освіти впродовж життя є Німецька Асоціація освіти дорослих (Der Deutsche Volkshochschulverband - DVV) - галузеве об’єднання, що включає в себе понад 900 вищих народних шкіл в 16 федеративних землях Німеччини. Ця організація належить до складу европейської мережі закладів, які сприяють популяризації освіти впродовж життя. Вона визнана провідною у галузі освіти дорослих і міжнародного співробітництва. Впродовж 45 років це об'єднання підтримуе розвиток неперервної освіти в Німеччині. Вищезазначена організація має понад 200 партнерів у 30 країнах Африки, Азії, Латинської Америки та Свропи. Основна мета цієї організації полягае в забезпеченні навчальних можливостей «для кожного, в усьому світі, впродовж життя» (Education for everyone. Worldwide. Lifelong.) (Der Deutsche VolkshochschulVerband, 2018).

На сьогоднішній день учасники Німецької Асоціації освіти дорослих мають змогу брати участь в актуальних проектах організації. В рамках дослідження ми проаналізували проект «talentCAMPus» та багатомовний портал «Portal Deutsch». 
1) Проект «talentCAMPus» надає учасникам змогу скористатися актуальними безкоштовними пропозиціями культурного розвитку в рамках програми федерального міністерства освіти й науки «Kultur macht stark - Bündnisse für Bildung». Шляхом реалізації вищезазначеної програми федеральне міністерство освіти та науки надає підтримку позашкільним пропозиціям для культурної освіти до 2022 р. В місцевих освітніх спілках федеральних земель удосконалюють проекти та програми, які забезпечують доступність освіти для дітей, молоді та дорослих біженців. Завдяки активній участі населення в культурно-освітній діяльності люди розвивають і таким чином набувають важливі навички для успішного життя, здобувають особистісне визнання, що дає змогу бути впевненим у власних силах та майбутньому.

У концепції проекту «talentCAMPus» передбачено навчання дітей та молоді з 9 до 18 років 3 обмеженими можливостями під час канікул. Додатково надається можливість для навчання батьків, які їх супроводжують (проект «talentCAMPus Ferien»). Окрім того, е можливості для навчання молодих біженців з 18 до 26 років (проект «talentCAMPus 18plus»).

Заслуговуе на увагу освітній концепт «talentCAMPus mit begleitender Elternbildung», який передбачае рівноцінні компоненти з орієнтованими на навчання стандартними пропозиціями та можливостями для вільного культурного розвитку. Участь у проекті передбачае всебічний розвиток особистості та надає можливості для соціального навчання в групі. Проект зазвичай реалізується впродовж тижня (з понеділка по п’ятницю), навчальний процес триває повний робочий день (6-8 годин). У процесі розгляду та експертизи організація враховуе наступні критерії:

- якість внеску місцевого проекту для досягнення мети освітнього концепту «talentCAMPus» та програми «Kultur macht stark - Bündnisse für Bildung»;

- якість змістового та педагогічного концептів;

- переконливість визначення цільової групи;

- переконливість співпраці в місцевій спільноті;

- продуманість та економічна обгрунтованість використання коштів (TalentCAMPus-Kultur macht stark. Bündnisse für Bildung, 2018).

2) Багатомовний проект «Portal Deutsch» узагальнюе інформацію про актуальні можливості вивчення німецької мови в народних університетах та проводить всеохоплюючий огляд багатосторонніх можливостей для викладачів та студентів, які, перейшовши на сайт, можуть знайти інформацію про різносторонні освітні пропозиції, зокрема «Einstieg Deutsch - Das Lernangebot» («Вступ до німецької мови - навчальна пропозиція»), який надае інформацію про можливості вивчення німецької мови для біженців (Einstieg Deutsch - Das Lernangebot, 2018).

Окрім того, відвідувачам порталу пропонуються «Hеimat-Rezepte» («Рецепти з Батьківщини») та мобільні додатки для вивчення німецької мови. Учасники отримують доступ до навчальних матеріалів 3 додатками. Вся інформація стосовно навчання е безкоштовною для користувачів. Відділ «Рanorama» пропонуе найкращі приклади застосування передового досвіду, фахові статті, огляди актуальних проектів. Вищезазначений відділ покликаний сприяти обміну досвідом та налагодженню зв'язків між студентами та викладачами (Deutscher Volkshochschul-Verband, 2018).

Німецьке товариство академічної безперервної освіти (Deutsche Gesellschaft für wissenschaftliche Weiterbildung und Fernstudium) е об'єднанням, яке включає в себе понад 325 учасників з вищих навчальних закладів та центрів підвищення кваліфікації Німеччини, Австрії та Швейцарії. Головною метою вищезазначеного товариства є підтримка, координація та презентація заходів з підвищення кваліфікації та дистанційних курсів, які проводять вищі навчальні заклади. Велика увага приділяеться дистанційним формам навчання та сучасним технологіям у підвищенні кваліфікації дорослих (Deutsche Gesellschaft für wissenschaftliche Weiterbildung und Fernstudium, 2018).

Багаторічний досвід німецькомовних країн в галузі освіти дорослих і його позитивний вплив на розвиток освіченості суспільства спонукае освітню та наукову спільноту України до переосмислення прогресивних надбань та їх екстраполяції у вітчизняну систему освіти, зокрема:

- потребуе створення мережі інституту дорослих по вертикалі - від центральних освітніх установ до регіональних та місцевих;

- розробки концептуальних засад цієї ланки неперервної освіти, конкретизації змісту, форм, методів, засобів навчання дорослих;

- впровадження інноваційних проектів, які б забезпечували доступ дорослого населення до різних форм освіти впродовж життя, дозволяли б поглиблювати знання та удосконалювати професійну компетентність без відриву від виробництва.

Розробка системи освіти дорослих потребуе диференціації їі складових, зокрема, одним групам населення дасть можливість адаптуватися до швидкозмінних умов життя, іншим - забезпечить індивідуальні освітні потреби, професійне зростання тощо. Важливою в організації освітньої діяльності дорослих є розробка змісту програм навчання, які б відповідали різнорівневим 
можливостям та освітнім потребам громадян і забезпечували взаємозв'язок теоретичних знань з їх практичною підготовкою. Система освіти дорослих в Україні мае базуватись на національних цінностях і збагачуватись загальноєвропейськими.

Обговорення / Discussion. Забезпечення ефективного розвитку освіти дорослих $\epsilon$ актуальним для української держави, про що свідчить розробка проекту Закону України «Про освіту дорослих» (МОН приймае заявки до робочої групи з розроблення проекту Закону України «Про освіту дорослих», 2018).

3 огляду на це вищезазначена проблематика потребуе подальшої теоретичної розробки та практичної реалізації їі засад.

Концепцію освіти дорослих в Україні розроблено провідним вітчизняним науковцем Л. Лук'яновою. В цьому науковому доробку обтрунтовано доцільність розвитку освіти дорослих в Україні, окреслено актуальні проблеми сучасної освітньої сфери дорослих, визначено ії мету i завдання, запропоновано напрями розвитку вітчизняної освіти дорослих, етапи впровадження та очікувані результати в контексті глобалізації, інтеграції до европейського освітнього простору (Лук'янова Л., 2011).

На думку Л. Сігаєвої, однією з головних передумов повороту до освіти дорослих е зростання вимог на ринку праці до професіоналізму фахівців та їх компетентності (Сігаєва Л., 2010).

Український науковець I. Лещенко виокремлюе наступні причини відставання освіти дорослих України від практики провідних країн світу:

- недостатність наукового обгрунтування освітньої політики в цілому;

- зосередження уваги на проблемах дитячо-юнацької освіти;

- відсутність необхідної нормативно-правової бази;

- оцінювання потенційних можливостей освіти дорослих;

- замала кількість рекомендаційних документів міжнародних організацій;

- недостатне дослідження зарубіжного досвіду в цій галузі (Офіційний сайт проекту Global International Scientific Analytical Project, 2018).

Крім того, на сторінках освітянської преси та в мережі Інтернет проводиться публічне обговорення щодо вмотивованості дорослого населення навчатися впродовж життя та можливості застосування набутих знань в практичній діяльності. Зокрема, в рамках Форуму неформальної освіти дорослих «Освіта дорослих і розвиток громадянського суспільства» обговорювались проблеми, які набули дискусійного характеру, зокрема щодо навчальних програм з громадянської освіти: сучасні вимоги до змісту та методів (модератор Ю. Петрушенко); освіти для людей похилого віку та активне громадянство (модератор А. Моргун); місто, що навчається у формуванні активного громадянина (модератор С. Прийма); практичні аспекти співпраці педагогів-андрагогів і центрів освіти дорослих в Україні у формуванні громадянського суспільства (модератор Т. Сорочан) («Вік живи, вік учись» - Форум неформальної освіти дорослих).

Висновки / Conclusions. Розробка системи освіти дорослих та її впровадження в Україні на основі прогресивного досвіду европейських країн забезпечить особистісне та професійне зростання кожного громадянина України та сприятиме формуванню суспільства знань.

Вивчення проблематики розвитку освіти протягом життя в німецькомовних країнах дасть можливість удосконалити теоретичні засади досліджуваного процесу; розширити зміст, інноваційні практично-орієнтовані форми та методи роботи з дорослими в системі української освіти; розробити інноваційні концепції для практичного застосування у вітчизняній освітній практиці.

До перспективних напрямків досліджень у даній сфері вважаємо за доцільне віднести такі проблеми: використання новітніх технологій здобуття освіти впродовж життя, дослідження діяльності організацій в Україні, які сприяють розвитку освіти впродовж життя.

\section{Список використаних джерел і літератури / References}

1. «Вік живи, вік учись - Форум неформальної освіти дорослих. Взято 3 http://www.ukrpress.info/2017/11/04/forum-neformalnoyi-osvity-doroslykh/ (дата звернення 24.10.2018). / «Vik zhyvy, vik uchys» - Forum neformalnoi osvity doroslykh [«Live and learn» - Forum of informal adult education]. Retrieved from http://www.ukrpress.info/2017/11/04/forum-neformalnoyi-osvity-doroslykh/ (last accessed 20.10.2018). [in Ukrainian].

2. Лук'янова, Л. Б. (2011). Концепиія освіти дорослих в Украӥні. Ніжин: ПП Лисенко М. М. / Lukianova, L. B. (2011). Konzepziia osvity doroslykh v Ukraini [Conception of Adult Education in Ukraine]. Nizhyn: PP Lysenko M. M. [in Ukrainian].

3. Матіюк, Д. В. (2018). Розвиток освіти дорослих в німецькомовних країнах Європи. Актуальні проблеми сучасної науки і наукових досліджень, 10 (13), 179-181 / Matiiuk, D. V. (2018). Rozvytok osvity doroslykh v nimetskomovnykh kraiinakh Evropy [The development of adult education in the German-speaking countries of Europe]. Aktualni problemy suchasnoi nauky i naukovykh doslidzhen, 10 (13), 179-181. [in Ukrainian].

4. МОН приймае заявки до робочої групи з розроблення проекту Закону України «Про освіту дорослих». Взято 3 https://pedpresa.ua/187029-mon-pryjmaye-zayavky-do-robochoyi-grupy-z-rozroblennya-proektu-zakonu- 
ukrayiny-pro-osvitu-doroslyh.html (дата звернення 28.09.2018). / MON pryimaie zaiavky z rozroblennia Zakonu Ukrainy «Pro osvitu doroslykh». [Ministry of Education and Science accepts applications to the working group on the drafting on the law of Ukraine "About Adult Education»]. Retrived from: https://pedpresa.ua/187029-monpryjmaye-zayavky-do-robochoyi-grupy-z-rozroblennya-proektu-zakonu-ukrayiny-pro-osvitu-doroslyh.html (last accessed 28.09.2018). [in Ukrainian].

5. Офіційний сайт проекту Global International Scientific Analytical Project. Взято 3 http://gisap.eu/ru/node/1380 (дата звернення 28.09.2018). / Ofitsiinyi sait proektu Global International Scientific Analytical Project. [Official website of the project Global International Scientific Analytical Project]. Retrieved from http://gisap.eu/ru/node/1380 (last accessed 28.09.2018). [in Ukrainian].

6. Сігаєва, Л. Є. (2010) Розвиток освіти дорослих в Україні (друга пол. XX cm. - поч. XХI cm.) [моногр.]. Київ: ТОВ «ВД ЕКМО». / Sihaieva, L. Е. (2010) Rozvytok osvity doroslykh v Ukraini (druha pol. XX st. - poch. XXI st.) [The development of adult education in Ukraine (second half of the XX century - beginning of the XXI century)]. [monograph]. Kyiv: TOV «VD EKMO». [in Ukrainian].

7. Bundesinstitut für Berufsbildung. Retrieved from https://www.bibb.de/ (last accessed 05.10.2018) [in German].

8. Council of Europe. Formal, non-formal and informal learning. Retrieved from https://www.coe.int/en/web/lang-migrants/formal-non-formal-and-informal-learning (last accessed 04.10.2018) [in English].

9. Deutsche Gesellschaft für wissenschaftliche Weiterbildung und Fernstudium. Retrieved from https://dgwf.net/ (last accessed 18.10.2018) [in German].

10. Deutsches Institut für Erwachsenenbildung. Leibniz-Zentrum für lebenslanges Lernen. Retrieved from https://www.die-bonn.de/institut/default.aspx (last accessed 05.10.2018) [in German].

11. Der Deutsche Volkshochschul-Verband. Retrieved from https://www.volkshochschule.de/ueber-uns.html (last accessed 08.10.2018) [in German].

12. Deutscher Volkshochschul-Verband. Portal Deutsch. Retrieved from https://portal-deutsch.de/panorama/ (last accessed 15.10.2018) [in German].

13. Einstieg Deutsch - Das Lernangebot. Retrived from http://www.ich-will-lernen.de/ (last accessed 12.10.2018) [in German].

14. Official site of andragogy lead by Professor J. Raistmann, Bamberg University. Retrieved from http://www.andragogy.net (last accessed 01.10.2018) [in English].

15. TalentCAMPus-Kultur macht stark. Bündnisse für Bildung. Retrieved from https://www.talentcampus.de/start/ (last accessed 10.10.2018) [in German].

16. UNESCO Institute for Lifelong Learning. Retrieved from http://uil.unesco.org/adult-education/confintea (last accessed 03.10.2018) [in English].

Дата надходження статті: «26» жовтня 2018 р.

Стаття прийнята до друку: «20» листопада 2018 р.

Хамська Неліна - доцент кафедри педагогіки і професійної освіти Вінницького державного педагогічного університету імені Михайла Коцюбинського, кандидат педагогічних наук, доцент

Khams'ka Nelina - assistant professor of the department of pedagogy and professional education of the Vinnytsia Mykhailo Kotsiubynskyi State Pedagogical University, candidate of pedagogical sciences, associate professor

Матіюк Дмитро - аспірант кафедри педагогіки і професійної освіти Вінницького державного педагогічного університету імені Михайла Коцюбинського

Matiiuk Dmytro - postgraduate student of the department of pedagogy and professional education of the Vinnytsia Mykhailo Kotsiubynskyi State Pedagogical University

\section{Цитуйте ијю статтю як:}

Хамська, Н. \& Матіюк, Д. (2018). Освіта дорослих в німецькомовних країнах та перспективні напрями їі розвитку в Україні. Педагогічний дискурс, 25, 79-84.
Cite this article as:

Khams'ka, N. \& Matiiuk, D. (2018). Adult Education in German-Speaking Countries and Perspective Directions of its Development in Ukraine. Pedagogical Discourse, 25, 79-84. 